\title{
PTGDS wt Allele
}

National Cancer Institute

\section{Source}

National Cancer Institute. PT GDS wt Allele. NCI Thesaurus. Code C159267.

Human PT GDS wild-type allele is located in the vicinity of $9 q 34.3$ and is approximately 7 $\mathrm{kb}$ in length. This allele, which encodes prostaglandin-H2 D-isomerase protein, plays a role in prostaglandin metabolism. 